\title{
"Functional and role-playing positions in modern management teams: an educational institution case study"
}

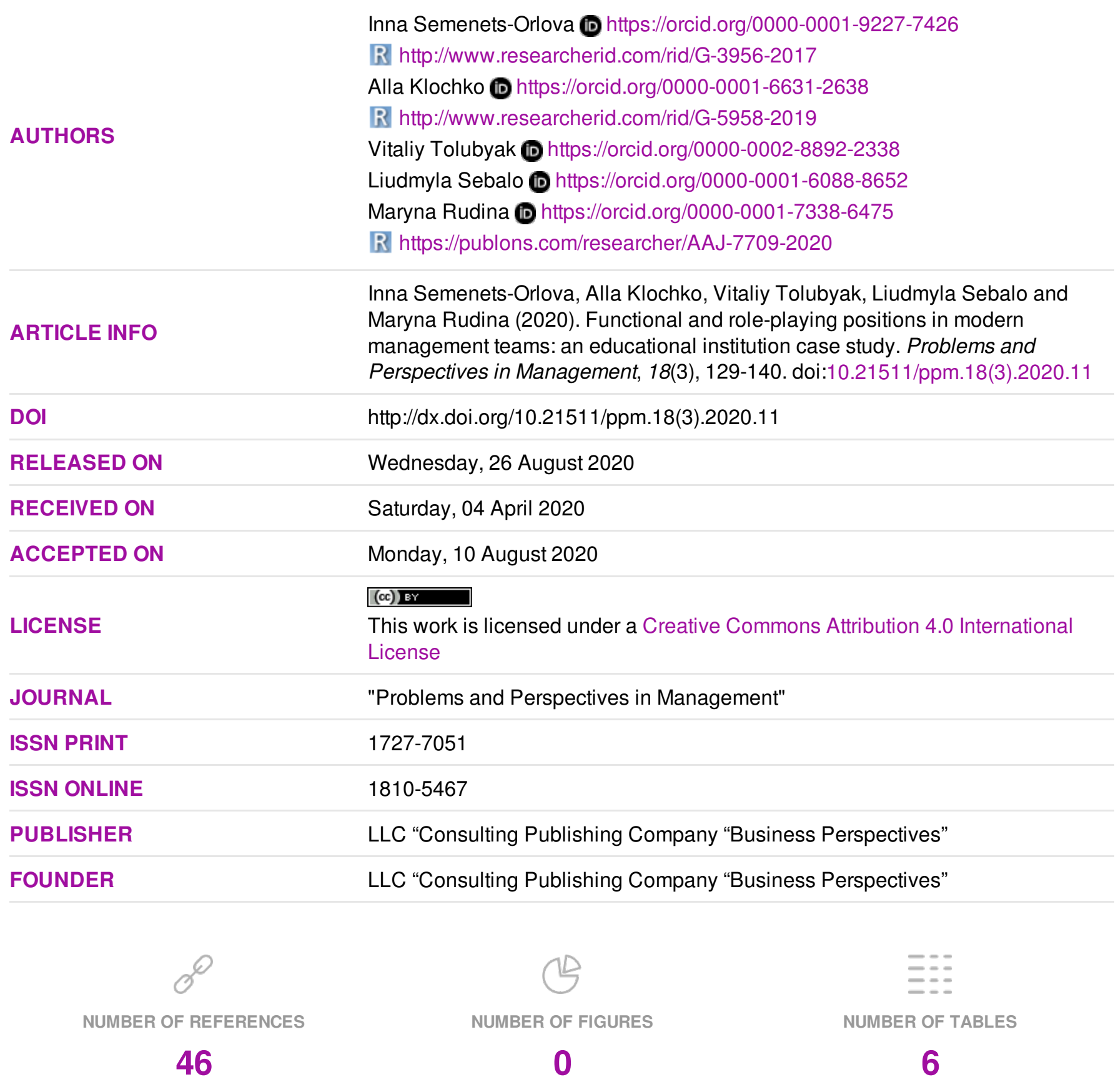

(c) The author(s) 2021. This publication is an open access article. 


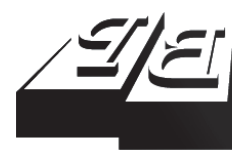

BUSINESS PERSPECTIVES

9

LLC "CPC "Business Perspectives" Hryhorii Skovoroda lane, 10, Sumy, 40022, Ukraine www.businessperspectives.org
Received on: $4^{\text {th }}$ of April, 2020 Accepted on: $10^{\text {th }}$ of August, 2020 Published on: $26^{\text {th }}$ of August, 2020

(C) Inna Semenets-Orlova, Alla Klochko, Vitaliy Tolubyak, Liudmyla Sebalo, Maryna Rudina, 2020

Inna Semenets-Orlova, Doctor of Public Administration, Associate Professor, Head of the Department of Public Administration, Interregional Academy of Personnel Management, Ukraine. (Corresponding author)

Alla Klochko, Ph.D. in Pedagogy, Associate Professor, Senior Research, Advanced Distributed Learning Center National Defence University of Ukrain named after Ivan Cherniakhovskyi, Ukraine.

Vitaliy Tolubyak, Doctor of Public Administration, Associate Professor, Department of Management and Public Administration, Ternopil National Economic University, Ukraine.

Liudmyla Sebalo, Ph.D. in Pedagogy, Associate Professor, Department of Pedagogy and Methods of Primary Education, National Pedagogical Dragomanov University, Ukraine.

Maryna Rudina, Ph.D. in Pedagogy, Associate Professor, English Philology and Translation Department, National Aviation University, Ukraine.

This is an Open Access article, distributed under the terms of the Creative Commons Attribution 4.0 International license, which permits unrestricted re-use, distribution, and reproduction in any medium, provided the original work is properly cited.

Conflict of interest statement: Author(s) reported no conflict of interest
Inna Semenets-Orlova (Ukraine), Alla Klochko (Ukraine), Vitaliy Tolubyak (Ukraine), Liudmyla Sebalo (Ukraine), Maryna Rudina (Ukraine)

FUNCTIONAL

AND ROLE-PLAYING POSITIONS

IN MODERN MANAGEMENT TEAMS:

AN EDUCATIONAL INSTITUTION CASE STUDY

\begin{abstract}
The analysis of scientific approaches to understanding the psychological characteristics of the role of the management team is important in the context of ensuring the organizational development of educational institutions. The purpose of the study is to explore the basic approaches and views of modern researchers on defining team roles, to identify the main functional and role positions in the management team.

Determining the types of leadership roles of educational institutions based on empirical research data. Also based on the method of case studies problem-situational analysis - solving leadership problems by educational managers - were analyzed the effectiveness of role-playing positions in management teams. Conclusions were made about the need for some correction of understanding and assessment of the importance of all roles in the staff of heads of educational institutions. Each of these command roles related to specific personality traits identified by the tests.
\end{abstract}

An analysis of the orientation of education leaders towards team roles shows that they tend to focus on all team roles. However, one can say that some roles are more at tractive to researchers, while others are less attractive. The government can use the research findings to create and implement training programs for educational leaders.

$\begin{array}{ll}\text { Keywords } & \text { educational institutions, changes, team formation, } \\ \text { leadership }\end{array}$

JEL Classification D23, I21

\section{INTRODUCTION}

The individual and collective abilities of managers are becoming increasingly important to the rapidly changing modern world and social and economic growth. The effectiveness of any organization in private or public sector ultimately depends on the quality of managerial and supervisory capacity, intellectual adequacy and practical experience of managers. As the pressure from social changes, which brings new behaviors and attitudes to work, increases, the managers' task will become more complex.

Currently, many professional activities are increasingly moving to the field of project activities, where coordinated teamwork is important. Methodological developments and models for optimization of team and group work are actualized (Ruch, Gander, Platt, \& Hofmann, 2016). This issue is important when analyzing the building self-regulatory teams (Romanenko, 2016; Bayazitova, 2019). The organizational and managerial environment is radically changing and becoming more flexible and adaptable to changes. Flexibility and the ability to adapt to the system of subject-subject and subject-object social rela- 
tions lead to the emergence of new horizontal ties and new spheres of communication, the formation and development of a meaningfully different cultural and organizational environment.

The trend of transition to "learning organizations" is associated with this; it is characterized by management systems that work on the principles of self-governing work teams. They are one of the mechanisms for improving the organizational structures and cultures of modern enterprises, where the structure is created around horizontal workflows, rather than around the functions of departments (Wilson, 1995).

Managing an organization becomes a business that affects everyone. The widespread use of self-governing work teams in organizations of various types shows that these forms of work organization are potentially more effective than traditional groups in terms of speed of response to the situation and the quality of decision-making (Harzer \& Ruch, 2014).

Particular attention is paid to the analysis of social factors that contribute to the effective implementation of productive work teams in management practice (J. Dyer \& W. Dyer, 2013). Studying the phenomenon of the team, the factors of its formation, development and functioning, in the 1980-90s a separate branch of scientific knowledge in the field of personnel management, called "team management", formed in the scientific world (Belbin, 1981; Tannenbaum, Beard, \& Salas, 1992).

During the constant changes and innovations in the education system, changes are made to the management system. The new paradigm of education has changed the relationship between the heads of educational organizations and teachers. The main principle on which the activity of the management team is based is the principle of joint activity. For teams working in an ever-changing environment, it is important to consider the balance of "team roles" that facilitates the interaction of one team member with another, in which the actions of each team member correspond to the overall effort to succeed.

Educational management is similar to management in other areas (Connolly, James, \& Fertig, 2017). In addition, the techniques of forming a team borrowed from the private sector to the public sector will be useful (Amanchukwu, Stanley, \& Ololube, 2015).

This work considers approaches to building a management team using the example of education. The selection of functional roles of managers has a major impact on the effectiveness of teamwork.

\section{LITERATURE REVIEW}

This study emphasizes the consideration of the working team as a special form of organization of social relations, in terms of sociological theory of small groups (Katzenbach \& Smith, 1994; Tannenbaum, Beard, \& Salas, 1992), the paradigm of social actionism (A. Touraine), where the main role is given to the actor - the subject of action, who tends to fight, thus having the opportunity to transform themselves and the learning organization (Senge, 1994).

Given that the working team is a kind of small group, based on the development of the theory of small groups of domestic and foreign researchers, an important conclusion can be drawn about the possibility of applying all developments and research in small groups to study working teams.

The theoretical bases of the study are:

1) the theory of work teams (Weber, 1947);

2) research on issues of self-government and self-organization of teams (Prigogine \& Stengers, 1984).

The pedagogy of partnership and a new culture of governance and relationships in the educational environment are among the key principles of education reform (Bush, Bell, \& Middlewood, 2019). 
The professionalism of the modern head of the educational institution is determined by knowledge, skills that ensure effective management. Democratic values in the education system are formed at all levels - meaningful, organizational, functional and communicative (Semenets-Orlova, Klochko, Nestulya, Mykhailych, \& Omelyanenko, 2019). Such approaches, during the social and economic development in Ukraine, have become the basis for renewing the management of the educational institution.

This study accepts Kozlowski and Bell's (Kozlowski \& Bell, 2003, p. 334) definitions of the teams, according to which the team consists of two or more persons that:

- perform organizational tasks;

- share the same targets;

- interact socially;

- perform interrelated tasks;

- $\quad$ are embedded in the corporate context.

According to Esther Cohen, creating a team is a process whereby organizations enable people to come together and form a cohesive team. In fact, building a team is a human management activity (Cohen, 2017). Any team consists of two types of relationships, in particular, relationships between individual team members and relationships between individuals and the team as a whole (Tannenbaum, Beard, \& Salas, 1992). Team building smoothes and defines these relationships using a combination of measures, rules and processes, active and passive practices.

It is important to find out the possibilities of revealing the social and managerial potential of a productive team. There are no studies on the analysis of the perception of roles and contribution to teamwork (only inventory of the role of teams, self-perception in the team from Belbin). Questions about job satisfaction and productivity of individual team members remain open.

According to the theory of R. Meredith Belbin, an ideal manager is one who combines all the advan- tages of the above types of roles and at the same time deprived of their disadvantages, due to the contradiction of personal characteristics (Belbin, 1993). However, what is not available to one person can be successfully performed by a team whose personal characteristics include the qualities needed to implement all eight roles. This does not mean that the group must necessarily consist of eight people. Each person can perform several roles, but usually not very many, no more than two or three. The main requirement is that all functions are performed. The full role structure creates the basis for the effective work of the team as a whole.

According to Shams (2019), cross-functional areas of business or public organizations play an important role in management Awareness and practical application of different roles by managers positively affect the performance of organizations.

Czech scientists put forward the concept of competence-based model roles of a manager, focused on a manager's ability to actively and creatively adapt to changing environment, as well as on their ability to regulate negative psychological impacts (Podhorec, Hrinic, \& Lakos, 2017).

P. Drucker describes a perfect manager as a person who always adheres to a single administrative style (Druker, 2003). One can agree with I. Adizes' point of view that theorists sometimes do not take into account the fact that different people may have different approaches to organization, control and motivation (Adizes, 2004. p. 12). The basic management style, according to I. Adizes, is a combination of four functions that must be performed to develop an organization (see Table 1). If one of these functions is not performed at all, it makes the whole management system incapable.

According to Kaydashev and Romanenko (2017), in public organizations, it is especially important for a manager to use psychological methods of recruitment for appointment to the relevant position. As Holovatyi (2014) points, the development of organizations depends on the ability of a manager to take multicultural factors into account.

Moga (2017) develops a scheme for Babin about nine possible team members and discusses the 
Table 1. Main functions of a manager that define management style according to I. Adizes (Adizes, 2004)

\begin{tabular}{l|c|c|c}
\hline \multicolumn{1}{c|}{ Entry } & Emphasis & Transformation & Exit \\
\hline Functions & Type of tasks & To make an organization & Characterizing activity \\
\hline P (Producing results) & What? & Functional & In temporary \\
\hline A (Administering - administration) & How? & Systematized & Effective \\
\hline $\begin{array}{l}\text { E (Entrepreneuring - Initiative, } \\
\text { openness to change) }\end{array}$ & When? & $\begin{array}{c}\text { Ready for forward action, } \\
\text { forward-looking }\end{array}$ & Productive \\
\hline I (Integrating - integration) & Who? & Complete & In a short term \\
\hline
\end{tabular}

harmonization of team roles in the case of small teams. The researcher gives reasons to once again pay attention to the need for an effective distribution of roles among team members. It is important to understand that the task facing the team defines the roles in the group, and depending on the task, the roles can change.

According to Morgeson, Scott, and Karam (2010), there are potentially several criteria of the team's effectiveness that cover affective (personal pleasure, devotion and identification), behavioral (quality and quantity of task completion, the context of activity, assistance to other members of the team, attraction to pro-social behavior), and cognitive (training and adaptation over time within the team) aspects.

In terms of evaluation goals, there are at least three different goals to evaluate a team: 1) the effectiveness of formal leaders; 2 ) the results of teamwork regardless of who performs the leading function; and 3) the team's success in achieving its goals (Kaiser, Hogan, \& Craig, 2008).

As Kozlowski and Bell (2003) note, advanced information and communication technologies provide new tools to better connect people on a team in real time and even allow teams to be virtual.

Over the past fifteen years, group and team researches have become increasingly focused on organizational psychology and organizational behavior (Wyk \& Marumoloa, 2012).

Creating a team is a permanent process that helps a working group to become a cohesive unit (Eisenhardt, Kahwajy, \& Bourgeois, 2009). Team members not only share hopes of performing group tasks but also trust and support each other and respect individual differences.
According to Sheard and Kakabadse (2007), a role perspective (leadership roles in formal, informal or temporary leadership groups or in general team of organization) can provide insight into a distributed and networked form of leadership.

Researchers agree that the areas of potential conflict and misunderstanding in teams and pairs respectively are not completely analyzed (Wyk \& Marumoloa, 2012).

Therefore, the aim of this paper is to analyze the role-based approach to management of team building (based on the sociological research).

\section{GENERALIZATION OF THE MAIN STATEMENTS}

Team Roles are used to identify behavioral strengths and weaknesses in the workplace. Role-playing positions ensure confidence in making decisions that involve people, and individuals and teams communicate and work together with better understanding. Teams offer diversity, address more complex problems, deliver faster results and can mirror organizational values. Modern researchers note that Belbin Team Roles can help select people to form high-performing teams and bring multi-functional teams together (Holloway, Nielsen, \& Saltmarsh, 2017). For evidence-based generalization of the main statements, a sociological analysis was carried out.

The study was conducted in 2019 on the basis of educational institutions from five regions of Ukraine. 253 heads of educational institutions attended the survey.

The organization of the study was based on common approaches to implementing a psychological 
research. Mathematical processing of data was performed using the statistical package SPSS (version 22). Descriptive statistics, related tables, and factor analysis were used for statistical processing and analysis of data.

The study used R. M. Belbin's technique for diagnostics of functional and role positions in the management team to determine the roles required in the activities of management teams of educational institutions (Belbin, 2011). The methodology provides an opportunity to study the orientation of the head and staff of educational institutions to the most suitable roles for them from those traditionally allocated to ensure the effective operation of the team: "Head"; "Former"; "Idea Generator"; "Idea Evaluator”; "Work Organizer”; "Group Organizer”; "Resource Researcher"; "Finisher".

The term "command role" primarily characterizes the characteristics of human behavior and interaction of a man at work. A command role describes a pattern of behavior, promotes interaction between one team member and others, in which the actions of each team member respond to a common efforts to achieve success.

An analysis of the orientation of education managers towards team roles (Table 2) shows that they are generally focused on all team roles. However, some of the roles are more attractive to the researchers, while others are less attractive.

Table 2. Levels of development of the main roles in the management team of heads of educational institutions (\% of the total number of respondents)

\begin{tabular}{l|c:c|c}
\hline \multirow{2}{*}{$\begin{array}{c}\text { Components of } \\
\text { administrative activities }\end{array}$} & \multicolumn{3}{|c}{ Development levels } \\
\cline { 2 - 4 } & High & Middle & Low \\
\hline Work organizer & 58.6 & 28.8 & 12.6 \\
\hline Group organizer & 56.0 & 32.2 & 11.8 \\
\hline Head & 23.8 & 42.2 & 34.0 \\
\hline Finisher & 23.5 & 37.2 & 39.3 \\
\hline Ideas evaluator & 19.7 & 43.2 & 37.2 \\
\hline Resource researcher & 19.4 & 46.6 & 34.0 \\
\hline Team former & 17.4 & 41.7 & 40.9 \\
\hline Idea generator & 16.0 & 34.5 & 49.5 \\
\hline
\end{tabular}

The study shows that the most attractive roles for the heads of educational institutions are "work organizer" (58.6\% of respondents have a high level of orientation to perform this role) and "group organizer" $(56.0 \%$ have a high level of orientation to this role), which, in turn, confirms the compliance of these roles with the directions of professional activity of a manager: psychological provision of positive climate in a team, establishment of partnership relations.

At the same time, this draws attention to the fact that the more "leadership" role of the "head" is directed towards significantly fewer studies. Thus, a high level of staff orientation towards this role was recorded only in $23.8 \%$ of respondents. This is explained by the formalized structure of educational institutions, when the main directions of work and decision-making can "descend" from above, staff has certain restrictions and occupies mainly the role of "performer."

In addition, it should be noted that the role of a "finisher" is presented at a low level among all the roles investigated (39.3\%). That is, firstly, there is a certain problem with bringing the initiated cases to their logical conclusion. This situation, which is quite common for professional activities, may be due to the need for the heads of educational institutions to conduct many cases and directions simultaneously, as well as to the lack of time, physical forces, material resources, etc. It is therefore desirable to introduce this role to carry out a full cycle of activities from the start of the case to its end.

The fact of orientation of $19.7 \%$ of managers towards the role of an "ideas evaluator" was also interesting. It turned out that only $19.4 \%$ of respondents act as researchers of resources for their implementation.

$17.4 \%$ of respondents have a high level of orientation towards the role of a "team former." $16.0 \%$ of managers have a high level of orientation towards the role of the "ideas generator". This indicates a rather low orientation towards research and creative roles.

The obtained data show the need for a certain correction of understanding and assessment of the importance of all roles in the team by the heads of educational institutions.

Each of these team roles relates to specific personal characteristics identified using tests (Table 3 ). 
Table 3. Characteristics of team roles

\begin{tabular}{|c|c|c|}
\hline Role name & Characteristic & Weaknesses \\
\hline \multirow{3}{*}{ “Head" } & Functions: takes different viewpoints and makes decisions & \multirow{3}{*}{$\begin{array}{l}\text { Ordinary in terms of intelligence and } \\
\text { ability. "Head" and "Former" cannot act } \\
\text { comfortably in the same team }\end{array}$} \\
\hline & Features: can listen, speaks well, logical, determined & \\
\hline & Type: a calm and stable personality needs a highly motivated group & \\
\hline \multirow{3}{*}{ "Former" } & $\begin{array}{l}\text { Functions: a leader who unites the efforts of the members of the } \\
\text { group into a single whole }\end{array}$ & \multirow{3}{*}{$\begin{array}{l}\text { Inclined to irritation, intolerance, } \\
\text { disappointment, suspicious. Affects other } \\
\text { people's feelings }\end{array}$} \\
\hline & Features: dynamic, determined, persistent & \\
\hline & Type: dominant extrovert needs a competent, holistic group & \\
\hline \multirow{3}{*}{$\begin{array}{l}\text { "Ideas } \\
\text { Generator" }\end{array}$} & Functions: source of ideas & \multirow{3}{*}{$\begin{array}{l}\text { Underestimates practical details. Considers } \\
\text { bureaucratic documents as an attack to his } \\
\text { freedom }\end{array}$} \\
\hline & Features: smart, rich imagination, creativity & \\
\hline & $\begin{array}{l}\text { Type: non-standard personality needs a motivated environment that } \\
\text { will perceive his ideas }\end{array}$ & \\
\hline \multirow{3}{*}{ "Ideas Evaluator" } & Functions: analysis and control of logical conclusions & \multirow{3}{*}{$\begin{array}{l}\text { Lack of inspiration and ability to encourage } \\
\text { others to act, weak focus on personal } \\
\text { success }\end{array}$} \\
\hline & $\begin{array}{l}\text { Features: analytical, intellectual, erudite, anchor of the group, returns } \\
\text { to reality }\end{array}$ & \\
\hline & $\begin{array}{l}\text { Type: sensible, strong-willed personality, needs to update information } \\
\text { and new ideas }\end{array}$ & \\
\hline \multirow{3}{*}{$\begin{array}{l}\text { "Work } \\
\text { Organizer" }\end{array}$} & $\begin{array}{l}\text { Functions: transformation of ideas into specific tasks and organization } \\
\text { of their implementation }\end{array}$ & \multirow{3}{*}{$\begin{array}{l}\text { Lack of flexibility, resistance to unverified } \\
\text { ideas, slow response to new opportunities }\end{array}$} \\
\hline & Features: organizer, strong-willed, resolute & \\
\hline & $\begin{array}{l}\text { Type: strong-willed personality, needs suggestions and ideas of the } \\
\text { group }\end{array}$ & \\
\hline \multirow{3}{*}{$\begin{array}{l}\text { "Group } \\
\text { Organizer" }\end{array}$} & $\begin{array}{l}\text { Functions: promotes agreement in the group, resolves } \\
\text { misunderstandings, and familiar with the needs, problems of the } \\
\text { members of the group }\end{array}$ & \multirow{3}{*}{$\begin{array}{l}\text { Can be indecisive at crucial moments. Can } \\
\text { be easily influenced by someone. Speaks } \\
\text { less than others }\end{array}$} \\
\hline & Features: sensitive, tactful, kind, communicative & \\
\hline & $\begin{array}{l}\text { Type: empathic and communicative personality, requires constant } \\
\text { contact with all members of the group }\end{array}$ & \\
\hline \multirow{3}{*}{$\begin{array}{l}\text { "Resources } \\
\text { Researcher" }\end{array}$} & Functions: connection with the environment & \multirow{3}{*}{$\begin{array}{l}\text { Loses interest to work when his initial } \\
\text { appeal passes }\end{array}$} \\
\hline & $\begin{array}{l}\text { Features: communicative, inclined to be interested, energetic, } \\
\text { charming }\end{array}$ & \\
\hline & Type: persistent extrovert, needs freedom of action & \\
\hline \multirow{3}{*}{ "Finisher" } & $\begin{array}{l}\text { Features: encourages the group to do everything on time and to the } \\
\text { end }\end{array}$ & \multirow{3}{*}{$\begin{array}{l}\text { Prone to worry about little things. Reluctant } \\
\text { to delegate authority, may be overly critical }\end{array}$} \\
\hline & Features: professional, pedantic, mandatory, responsible & \\
\hline & Type: pedantic personality requires group responsibility, mandatory & \\
\hline
\end{tabular}

Since an important principle of team work is the complementarity (interchangeability) of roles and the definition of roles required in the activities of teams of educational institutions (Holloway, Nielsen, \& Saltmarsh, 2017), a factor analysis of data was carried out, reflecting the orientation of heads of educational institutions towards the main roles in the team. Factor analysis showed three leading factors that reflecting the orientation of heads of educational institutions towards the main roles in the team (Table 4).

The content and the structure (set of roles) of each of the selected factors were analyzed (Table 4).

Table 4. Management components of heads of educational institutions (based on factor analysis results)

\begin{tabular}{|c|c|c|c|}
\hline \multirow{3}{*}{ Components of administrative activity } & \multicolumn{3}{|c|}{ Factors } \\
\hline & 1 & 2 & 3 \\
\hline & "Initiation" & "Formation" & "Search" \\
\hline Ideas generator & 0.580 & - & - \\
\hline Group organizer & -0.743 & - & - \\
\hline Team former & - & 0.523 & - \\
\hline Head & - & 0.464 & - \\
\hline Ideas evaluator & - & 0.441 & - \\
\hline Work organizer & - & -0.787 & - \\
\hline Resources researcher & - & - & 0.800 \\
\hline Finisher & - & - & -0.567 \\
\hline
\end{tabular}


The first factor ("Initiation") combines command roles such as "ideas generator" (0.580) and "group organizer" $(-0.743)$. The first trend of this factor represents the orientation of a certain part of managers towards the role, which ensures the application of a creative approach, the development of innovative and non-standard ideas in the activities of the team. The second trend relates to the exercise of emotional leadership related primarily to human orientation. It functions with the help of a "group organizer" (facilitating agreement in the group, resolving misunderstandings, knowledge and helping to solve the needs, problems of group members).

The second factor ("Formation") consists another set of roles, which are necessary for the successful operation of teams in educational institutions. One component of the second factor indicates the orientation of a certain group of managers to such roles, which ensure the solution of strategic objectives. This is done through the implementation of the functions of "head" (0.464), "ideas evaluator" (0.441) (establishing and maintaining contacts with the external environment, analysis of proposed ideas, perception of different points of view and decisionmaking). Another component determines the orientation of a certain part of management staff to perform daily tasks. This is realized with the help of the functions of "work organizer" (-0.787) and "shaper" (0.523) (transformation of ideas into specific tasks and organization of their implementation).

It is very important to combine strategic and tactical roles in one team. After all, this is confirmed by the principle of complementarity of roles, which is one of the main features of teamwork. Secondly, when in the process of performing practical work team members need to work along with the technical performance of work tasks for the future and develop a basic strategy for the whole team in the practical sphere, it is very important.

The third factor ("Search"), which includes the roles of "resources researcher" $(0.800)$ and "finisher" (-0.567), can be interpreted as a factor of bringing logical conclusions and encouraging the group to do everything on time and to the end.

Therefore, the results of the factor analysis showed the possibility of a certain "compression" of roles, can serve as the basis for modernizing the classical role structure of the management team of an educational institution. Three main roles are sufficient for successful functioning of the team in modern conditions, which will cover the performance of all functions presented in the 8-role structure of the team according to Belbin (2011). The roles "Initiator," "Former", and "Searcher" can determine the role structure of the management team of an educational institution.

\section{DISCUSSION}

I. Adizes is convinced that the management system is especially specific in the field of education and culture, but his author's management formula is called suitable for any area where changes occur. According to the scientist, the leader is the one who successfully performs at least two specific functions (productive or administration or entrepreneurship), one of which is integration (I) (Adizes, 2004, p. 14). In addition, the style of leadership should correspond to the nature, the stage of implementation of the current task and the specific life cycle of thane organization. If a certain function in the management activity of a manager is shown successfully, I. Adizes proposes to write a large letter corresponding to the successful function (P, A, E or I), if it is at a sufficient level - a lower letter (p, a, e or i), if not shown - minus (-), according to the formula of his style.

American psychologist D. Goleman, having investigated various components of emotional intelligence (Goleman, 2000), concluded that managers apply six styles of the leadership practice in various fields of activity. In this study, these types are considered very suitable for education, with an emphasis on interpersonal factors. They are analyzed by the criterion of influence on the organizational climate (Table 5).

According to Adizes, the structure of the management pyramid in any industry is usually very simple - there are carriers of E-function on the top (in the current system, these are implementors of the 1st order, which are authorized to determine the strategic course), on the level below - managers-carriers of A-functions (implementors of the 2nd order, which provide implementation of solu- 
Table 5. Influence of leadership styles on the effectiveness of educational change according to D. Goleman

\begin{tabular}{|c|c|c|c|c|c|}
\hline Style & $\begin{array}{l}\text { Head's line of } \\
\text { action }\end{array}$ & $\begin{array}{l}\text { The aspects of } \\
\text { emotional intelligence } \\
\text { that underlie the style }\end{array}$ & $\begin{array}{l}\text { Content of } \\
\text { style }\end{array}$ & $\begin{array}{c}\text { The situations in } \\
\text { which style is the } \\
\text { most effective }\end{array}$ & $\begin{array}{c}\text { Influence of style } \\
\text { on organizational } \\
\text { climate/Leadership } \\
\text { formula }\end{array}$ \\
\hline Directive & $\begin{array}{l}\text { Demands direct } \\
\text { submission }\end{array}$ & $\begin{array}{l}\text { Desire to achieve results, } \\
\text { initiative, self-control }\end{array}$ & $\begin{array}{l}\text { "Do what I tell } \\
\text { you to do" }\end{array}$ & $\begin{array}{c}\text { In crisis situations, if } \\
\text { necessary, to restore the } \\
\text { system to a better state, } \\
\text { a problematic team of } \\
\text { employees }\end{array}$ & Negative/pAei \\
\hline Inspiring & $\begin{array}{l}\text { Mobilizes the team } \\
\text { around its vision of } \\
\text { the future }\end{array}$ & $\begin{array}{c}\text { Self-confidence, } \\
\text { effectiveness of proposed } \\
\text { changes, empathy }\end{array}$ & "Follow me" & $\begin{array}{l}\text { If necessary, radical } \\
\text { new concept, course } \\
\text { of organizational } \\
\text { development }\end{array}$ & $\begin{array}{l}\text { In most cases } \\
\text { positive/p-El }\end{array}$ \\
\hline Supporting & $\begin{array}{l}\text { Creates harmony, } \\
\text { promotes emotional } \\
\text { contacts }\end{array}$ & $\begin{array}{l}\text { Empathy, ability to build } \\
\text { relationships, the art of } \\
\text { communication }\end{array}$ & "Team first of all" & $\begin{array}{l}\text { To increase the } \\
\text { motivation of employees } \\
\text { in stressful situations }\end{array}$ & Positive/pael \\
\hline Democratic & $\begin{array}{l}\text { Agreement } \\
\text { through collective } \\
\text { participation in } \\
\text { problem-solving }\end{array}$ & $\begin{array}{l}\text { Team collaboration, } \\
\text { the art of collective } \\
\text { decision-making }\end{array}$ & $\begin{array}{l}\text { "«What's your } \\
\text { point of view"? }\end{array}$ & $\begin{array}{l}\text { If necessary, to reach } \\
\text { agreement, broad } \\
\text { collective participation } \\
\text { to find out the point of } \\
\text { view of employees }\end{array}$ & Positive/p-El \\
\hline "Adjusting" & $\begin{array}{l}\text { Sets high } \\
\text { performance } \\
\text { standards }\end{array}$ & $\begin{array}{l}\text { Commitment and self- } \\
\text { control, confidence in } \\
\text { change management, } \\
\text { initiative }\end{array}$ & "Do as I do" & $\begin{array}{l}\text { If necessary, to achieve } \\
\text { a quick result with the } \\
\text { team of highly qualified } \\
\text { and motivated specialists }\end{array}$ & Negative/P-Ei \\
\hline Advisory & $\begin{array}{l}\text { Prepares people for } \\
\text { future challenges }\end{array}$ & $\begin{array}{l}\text { Development of other } \\
\text { members of the team, } \\
\text { empathy, self-perception }\end{array}$ & $\begin{array}{l}\text { "Try in such a } \\
\text { way" }\end{array}$ & $\begin{array}{l}\text { To help an employee } \\
\text { improve efficiency or } \\
\text { develop the qualities } \\
\text { needed in a long term }\end{array}$ & Positive/P-el \\
\hline
\end{tabular}

tions), at the base of the pyramid - performers carriers of dominant P-function (implementors of the $3^{\text {rd }}$ order) (Adizes, 2004). However, one can agree with the point of view of I. Adizes that such a pyramid is still somewhat outdated and will not work quite effectively, because it is suitable only for routine decisions (Leithwood, 1992; Burnes, 2015). Besides, as practice shows, over time in such a pyramid the number of carriers of A-function grows very quickly, not in favor of carriers of Eand P-functions. Thus, with the previous amount of work, the number of people who follow the implementation process is steadily increasing. This makes it difficult to make decisions and implement them. Most often, when the implementor of style -A-- gets increase and becomes responsible for performing the E-function, it should not be expected to quickly become a successful implementor E. Ideally, a manager should be an implementor of the PaEI-style. As practice shows, this happens rarely since the best specialists are not always capable integrators.

As can be seen, apart from the directive style, which is expedient only in crises and in conditions of urgent introduction of particularly important changes, there is no dominant bureaucratic component of "A-function" in any leadership formula above. However, each formula has an integrative component of greater (I) or lesser degree (i). It is interesting that I. Adizes calls the speakers of style PaEI the leaders of transformation (Adizes, 2004). That fact that the RaEI formula does not exist in any of the leadership style analyzed above demonstrates the desirability of combining some styles in the change management process (Table 6).

It is important that at the stage of initiation of educational change, each educational manager must be a member of the project group, but not necessarily its head (Katzenbach \& Smith, 1993, 2003; Stalnaker, 2018). This important point should be taken into account for targeting, planning the algorithm of actions to implement the change, organizing its implementation, monitoring the implementation on democratic principles of management.

It should be stressed that the effective work of the team requires the role of a "business leader" and 
Table 6. Dependence of leadership styles on the context of the implementation of organizational change

\begin{tabular}{|c|c|c|c|c|}
\hline Style & $\begin{array}{c}\text { Context, most appropriate type } \\
\text { of changes }\end{array}$ & Resource dependency & $\begin{array}{c}\text { Temporal prospect } \\
\text { of efficiency }\end{array}$ & $\begin{array}{c}\text { Change lifecycle } \\
\text { stages* }\end{array}$ \\
\hline Directive & $\begin{array}{l}\text { Operational objectives, individual } \\
\text { piecemeal changes with limited } \\
\text { consequences, spontaneous changes } \\
\text { as a response to the need for rapid } \\
\text { adaptation to the variability of the } \\
\text { organizational environment, caused a } \\
\text { crisis in the functioning of the system or } \\
\text { its individual structures }\end{array}$ & $\begin{array}{l}\text { Material, temporary resources } \\
\text { should be in sufficient } \\
\text { quantity, there may be } \\
\text { problems with the personnel } \\
\text { resource; strong political will, } \\
\text { public demand for changes }\end{array}$ & Short-term & $3,4,5,6$ \\
\hline Inspiring & $\begin{array}{l}\text { Radical systemic changes, wide scale of } \\
\text { updates, strategic goals, strong need } \\
\text { to motivate employees to constantly } \\
\text { improving themselves, support in } \\
\text { adopting new progressive ideas in the } \\
\text { context of understanding the feasibility } \\
\text { of complex changes in education }\end{array}$ & $\begin{array}{c}\text { All resources in sufficient } \\
\text { quantity, a significant } \\
\text { degree of legitimacy of } \\
\text { deep educational changes } \\
\text { in society. In conditions of } \\
\text { need to develop a force field } \\
\text { of support for new, perhaps } \\
\text { somewhat incomprehensible } \\
\text { ideas }\end{array}$ & Long-term & $1,2,7$ \\
\hline Supporting & $\begin{array}{c}\text { Comprehensive reform continued under } \\
\text { conditions of low degree of confidence } \\
\text { of participants of changes to each } \\
\text { other (for example, low social status } \\
\text { of employees in the public sphere, and } \\
\text { society trusts their professionalism), } \\
\text { state stimulation to active innovation in } \\
\text { the field }\end{array}$ & $\begin{array}{l}\text { In the face of some shortage } \\
\text { of all types of resources } \\
\text { and crises that may result } \\
\text { from this; in the event of an } \\
\text { unexpected change in public } \\
\text { policy }\end{array}$ & Medium-term & $4,5,6$ \\
\hline Democratic & $\begin{array}{c}\text { Not immediate goal of systemic changes } \\
\text { in the absence (even at the paradigm } \\
\text { level) of a unified vision of educational } \\
\text { reform, as well as separate structural } \\
\text { changes in the regime of time trouble } \\
\text { and a significant level of novelty } \\
\text { of changes, the need to overcome } \\
\text { resistance to change at the individual } \\
\text { and organizational levels. Most effective } \\
\text { at the stage of discussion of the concept } \\
\text { of updates and public awareness } \\
\text { campaign }\end{array}$ & $\begin{array}{l}\text { Under conditions of sufficient } \\
\text { temporary resource. With } \\
\text { considerable clear and } \\
\text { hidden resistance to changes, } \\
\text { existence of significant } \\
\text { differences between the vision } \\
\text { of the content of the reformist } \\
\text { policy of the public and the } \\
\text { state. }\end{array}$ & $\begin{array}{l}\text { Effective - medium- } \\
\text { term, most effective } \\
\quad \text { - short-term }\end{array}$ & $\begin{array}{l}1,2,5 \text { and } \\
\text { preparation to } 6\end{array}$ \\
\hline Adjusting & $\begin{array}{l}\text { Operational objectives, consistent } \\
\text { changes with the lowest possible level } \\
\text { of resistance when there is a request in } \\
\text { society for a strong leader }\end{array}$ & $\begin{array}{c}\text { Significant resources } \\
\text { contributing to circumstances, } \\
\text { strong political will, motivated } \\
\text { human resources }\end{array}$ & $\begin{array}{l}\text { Short-term and } \\
\text { medium-term }\end{array}$ & $3,4,6$ \\
\hline Advisory & $\begin{array}{l}\text { Far-sighted, strategic goals, preparing } \\
\text { for public debate on reforms and } \\
\text { implementation of changes to overcome } \\
\text { resistance with considerable likelihood } \\
\text { of its manifestation in the strongest } \\
\text { form; for implementation of the reform } \\
\text { in the future }\end{array}$ & $\begin{array}{l}\text { Sufficient resources, } \\
\text { especially temporary } \\
\text { ones. Most effective in the } \\
\text { context of the paradigm } \\
\text { of strong organizational } \\
\text { learning embodied in public } \\
\text { organizations }\end{array}$ & Medium-term & $1,2,3,4,5,7$ \\
\hline
\end{tabular}

Note: * Explanations to the table: Stages of the life cycle of educational change: 1) conceptualization - the stage of formation of the idea (concept) of transformation; 2) design - definition of general contours of changes, justification; 3) design detailed study of individual elements of change, terms of precise implementation, economic parameters, and spheres of use; 4) technologization - preparation of relevant regulatory acts, for instance, with calculations of a new set of standards; 5 ) experimentation - testing of a small model in a limited but representative scale; 6 ) mastering - single or mass (diffuse propagation); 7) exhaustion of novelty and additional efficiency.

an "emotional leader" (Hura, 2018; Greenberg \& Baron, 1997; Johnson, 1993). The content of the second factor ("Formation") reflects another set of roles that are necessary for the success of teams in educational institutions.
The first trend reflects the orientation of a certain group of the heads towards such roles, which support strategic roles. This is done through the implementation of the functions of "head" and "idea evaluator" (setting and maintaining contacts with 
the external environment, analysis of proposed ideas, perception of different points of view and decision-making).

The second trend highlights the orientation of a certain part of management staff towards day-today tasks. It accomplished through the functions of a "work organizer" and a "former" (conversion of ideas into specific tasks and organization of their execution).
The importance of combining roles, both strategic and tactical, in one team should be emphasized (Cashman, 2008). After all, this is confirmed, first, at the level of theory, by the principle of complementarity of roles, which is one of the main features of teamwork. Second, when, in the process of carrying out practical work, team members need to work in the future along with the technical performance of work tasks and develop the main strategy for the entire team at the level of team practice.

\section{CONCLUSION}

The role structure in teamwork is an important success factor that can ensure the prosperity of both the team and the educational institution. In management theory, command processes occur in four main directions such as team building, team development, defining team roles, and building team cohesion. All these processes are interconnected and mutually consistent, since it is impossible to create a team without defining the role structure of its members.

There is a certain imbalance in the focus of the management staff of educational institutions on the performance of main roles in the team. The role structure of the management team of an educational institution can be modified compared to the traditional structure of the team. The results of the research show the need to introduce special psychological training to members of teams of educational institutions to form a role structure of the team and perform certain roles.

The obtained research results can be used by school heads to: a) determine the roles that the organization's employees focus on most and least of all (identifying "actually working" roles); b) identify "problematic" roles, i.e. those that are absent and that need to be introduced by its team activities to ensure its integrity and effectiveness (there is often an urgent need to introduce roles such as "ideas generator," "resources researcher", etc., which are not available or not sufficiently represented in many teams today); and c) select people for the team according to the identified orientations towards the most suitable roles for specific people.

\section{AUTHOR CONTRIBUTIONS}

Conceptualization: Inna Semenets-Orlova, Alla Klochko, Vitaliy Tolubyak.

Data curation: Maryna Rudina.

Formal analysis: Maryna Rudina, Vitaliy Tolubyak.

Investigation: Maryna Rudina, Liudmyla Sebalo.

Methodology: Liudmyla Sebalo, Alla Klochko.

Project administration: Inna Semenets-Orlova, Alla Klochko.

Supervision: Inna Semenets-Orlova, Vitaliy Tolubyak.

Validation: Alla Klochko, Liudmyla Sebalo.

Visualization: Alla Klochko, Maryna Rudina, Liudmyla Sebalo.

Writing - original draft: Inna Semenets-Orlova, Alla Klochko.

Writing - review \& editing: Inna Semenets-Orlova. 


\section{REFERENCES}

1. Adizes, I. (2004). Management/ Mismanagement Styles: how to identify a style and what to do about it. Santa Barbara: The Adizes Institute Publishing.

2. Amanchukwu, R., Stanley, G., \& Ololube, N. (2015). A Review of Leadership Theories, Principles and Styles and Their Relevance to Educational Management. Management, 5(1), 6-14. Retrieved from http://article.sapub. org/10.5923.j.mm.20150501.02. html

3. Barner, R., \& Charlotte, P. (2012). Building Better Teams: 70 Tools and Techniques for Strengthening Performance Within and Across Teams. John Wiley \& Sons Limited.

4. Bayazitova, D. (2019). Group work: peer assessment and rewards distribution. Organizational Psychology, 9(4), 174-184. Retrieved from https://orgpsyjournal.hse.ru/ en/2019-9-4/327934825.html

5. Belbin, R. (1981). Management teams. New York: Hamemann.

6. Belbin, R. (1993). Team roles at work. Oxford: ButterworthHeinemann

7. Belbin, R. (2011). Management Teams: Why They Succeed or Fail (3rd ed.). Human Resource Management International Digest, 19(3). https://doi.org/10.1108/ hrmid.2011.04419cae.002

8. Burnes, B. (2015). Understanding Resistance to Change - Building on Coch and French. Journal of Change Management, 15(2), 92-116. https://doi.org/10.1080/14697017.2 014.969755

9. Bush, T., Bell, L., \& Middlewood, D. (2019). Principles of Educational Leadership \& Management. London, SAGE.

10. Cashman, K. (2008). Leadership from the inside Out: Becoming a Leader for Life. San Francisco: Berret-roehler Publishers.

11. Cohen, E. (2017). The Definitive Guide to Team Building, Agency Management, Operational Excellence. Retrieved from https://www. workamajig.com/blog/team-building-guide
12. Connolly, M., James, C., \& Fertig, M. (2017). The difference between educational management adn educational leadership and the importance of educational responsibility. Educational Management Administration \& Leadership. https://doi. org/10.1177/1741143217745880

13. Druker, P. (2003). Management in the Next Society. New York: Truman Talley Books.

14. Dyer, J., \& Dyer, W. (2013). Team building: proven strategies for improving team performance. Jossey-Bass.

15. Eisenhardt, K., Kahwajy, J., \& Bourgeois, L. (2009). How Management Teams Can Have a Good Fight. Harvard Business Review, 75(4), 77-85. Retrieved from https://www.womeninanesthesiology.org/wp-content/ uploads/2018/02/HBR-how-management-teams-can-have-a-goodfight.pdf

16. Goleman, D. (2000). Leadership that gets results. UK: Harvard Business School Press.

17. Greenberg, J., \& Baron, R. (1997). Behavior in organizations. Understanding and managing the human side of work. New Jersey: PrinceHall International.

18. Guzzo, R., \& Dickson, M. (1996). Teams in organization: recent research on performance and effectiveness. Annual Review of Psychology, 47, 307-338. https:// doi.org/10.1146/annurev. psych.47.1.307

19. Harzer, C., \& Ruch, W. (2014). The role of character strengths for task performance, job dedication, interpersonal facilitation, and organizational support. Human Performance, 27, 183-205. Retrieved from https://www.researchgate.net/ publication/251560316_The Role_of_Character_Strengths_for Task_Performance_Job_Dedication_Interpersonal_Facilitation_ and_Organizational_Support

20. Holloway, J., Nielsen, A., \& Saltmarsh, S. (2017). Prescribed distributed leadership in the era of accountability: The experiences of mentor teachers. Educational Management Administration \& Leadership. https://doi. org/10.1177/1741143216688469

21. Holovatyi, M. (2014). The phenomenon of multiculturalism as a means of achieving interethnic unity of peoples and countries. Economic Annals-XXI, 11-12, 15-18.

22. Hura, T. (2018) Leadership Psychology in Business. Psychological Journal, 19(9), 138-151. https://doi. org/10.31108/1.2018.9.19.10

23. Johnson, S. (1993). Work Team: What's Ahead in Work Design and Rewards Management. Compensation and Benefits Review, 25(2), 35-41. https://doi. org/10.1177/088636879302500206

24. Kaidashev, R., \& Romanenko, Y. (2017). Psychological types in the specifics of the court activity. Scientific Bulletin of Polissia, 3(11), 177-183. Retrieved from http:// journals.uran.ua/nvp_chntu/article/view/121004

25. Kaiser, R., Hogan, R., \& Craig, S. (2008). Leadership and the Fate of Organizations. American Psychologist, 63, 96-100. https://doi. org/10.1037/0003-066X.63.2.96

26. Katzenbach, J., \& Smith, D. (1993). The Discipline of Teams. Harvard Business Review, 71(2), 111-119. Retrieved from https:// hbr.org/1993/03/the-discipline-ofteams-2

27. Katzenbach, J., \& Smith, D. (2006). The wisdom of teams: Creating the high-performance organization. New York: HarperCollins, Collins Business Essentials.

28. Katzenbach, J., \& Smith, O. (1994). The wisdom of teams: creating the high perfomance organization. New York: Harper Business.

29. Kozlowski, S., \& Bell, B. (2003). Work groups and teams in organizations. In W. C. Borman, D. R. Ilgen, \& R. J. Klimoski (Eds.), Handbook of psychology (Vol. 12): Industrial and Organizational Psychology (pp. 333-375). New York: Wiley. 
30. Leithwood, K. (1992). Toward Transformational Leadership. Educational Leadership, 49(5), 8-12.

31. Moga, B. (2017). Belbin Team Roles: Theory and Practice. Active Collab. Retrieved from https://activecollab.com/blog/collaboration/ belbin-team-roles-theory-practice

32. Morgeson, F., Scott, D., \& Karam, P. (2010). Leadership in Teams: A Functional Approach to Understanding Leadership Structures and Processes. Journal of Management, 36(1), 5-39. https://doi. org/10.1177/0149206309347376

33. Podhorec, M., Hrinic, P., \& Lakos, G. (2017). Leadership in the Process of Command and Control, Place and Role of CommanderManager. International conference KNOWLEDGE-BASED ORGANIZATION, 23(1). https://doi. org/10.1515/kbo-2017-0038

34. Prigogine, I., \& Stengers, I. (1984) Order out of chaos. New York, NY: Bantam Books.

35. Romanenko, Y. O. (2016). Place and role of communication in public policy. Actual Problems of Economics, 2(176), 25-31. Retrieved from https:// www.researchgate.net/publication/303153344_Place_and_role_ of_communication_in_public_policy
36. Ruch. W., Gander, F., Platt, T., \& Hofmann, J. (2016). Team roles: Their relationships to character strengths and job satisfaction. The Journal of Positive Psychology, 190-199. Retrieved from https://psycnet.apa.org/record/2018-01905-010

37. Semenets-Orlova, I., Klochko, A. Nestulya, S., Mykhailych, O., \& Omelyanenko, V. (2019). Readiness of the education manage to provide the organizational development of institutions (based on the sociological research). Problems and Perspectives in Management, 17(3), 132-142. https://doi. org/10.21511/ppm.17(3).2019.11

38. Senge, P. (1994). The Fifth Discipline Fieldbook: Strategies and Tools for Building a Learning Organization. Currency.

39. Shams, R. (2019). Cross-functional knowledge management. The international landscape. New York: Routledge.

40. Sheard, A., \& Kakabadse A. (2007). A role-based perspective on leadership as a network of relationships. Journal of Management Development, 26(4), 331-352. https://doi. org/10.1108/02621710710740093

41. Stalnaker, D. (2018). Industrial and Organizational Psychol- ogy: Humans and Organizations. https://doi.org/10.2139/ ssrn. 3271653

42. Tannenbaum, S., Beard, R., \& Salas, E. (1992). Team building and its influence on team effectiveness examination of conceptual an empirical developments. In K. Kelley (Ed.), Issues, Theory, and Research in Industrial Organizational Psychology. Elsevier Science Publishers. Retrieved from https://psycnet. apa.org/record/1992-98819-005

43. Touraine, A. (2000). A Method for Studying Social Actors. Journal of World-Systems Research, 6(3), 900-918. https://doi.org/10.5195/ jwsr.2000.211

44. Weber, M. (1947). The Theory of Social and Economic Organizations. Henderson, A. M., and Parsons, T. (trans.) New York: Oxford University Press.

45. Wilson, G. (1995). Self-Managed Teamworking. The Flexible Route to Competitive Advantage. London: Pitman Publishing.

46. Wyk, Ch., \& Marumoloa M. (2012). The Role and Functioning of School Management Teams in Policy Formulation and Implementation at School Level. Journal of Social Sciences, 32(1). https:// doi.org/10.1080/09718923.2012.1 1893056 